\title{
CLOSTRIDIA ISOLATED FROM FAECES
}

\author{
B. S. Drasar, P. Goddard, Sandra Heaton, Susan Peach \\ AND BERYL WEST \\ Bacterial Metabolism Research Laboratory, Colindale, London, NW9 5DX
}

CANCER of the colon may result from the action of carcinogens produced from steroids in the intestine by gut bacteria (Aries et al., 1969; Hill et al., 1971). Clostridia are among the most metabolically active of intestinal bacteria. Several species have been shown to degrade steroids (Norman and Grubb, 1955; Capek, Hanc and Tadra, 1966), and study of a strain of Clostridium paraputrificum showed that this organism produced a 3-oxo-5 $\beta$ steroid $\triangle^{4-}$ dehydrogenase (Aries, Goddard and Hill, 1971) which performs a key reaction in the production of the aromatic steroids postulated as possibly related to the causation of cancer of the colon. Further studies demonstrated that this enzyme is possessed by many strains of $C$. paraputrificum and related organisms (Goddard et al., 1975).

In the course of a study of faeces from groups of people in various parts of the world, in which the incidence of cancer of the colon varies widely, we isolated numerous clostridia. In the present paper we report on the identity of these isolates.

\section{MATERIALS AND METHODS}

Samples of faeces were obtained from groups of normal healthy adult men and women consuming a mixed western diet in England, Scotland and the USA, and from those consuming a diet rich in carbohydrate in Japan and Uganda (Hill et al., 1971; Peach et al., 1974). Samples from the USA came from both black and white persons.

Samples of faeces were also obtained from normal healthy adults, consuming the local diet, in Hong Kong. Additional samples of faeces from normal healthy adults aged between 45 and 75 years consuming a mixed western diet, in Wales, were obtained as part of a prospective study on the role of clostridia and steroids in the development of cancer of the colon.

Transport and storage of specimens. Fresh samples of faeces were diluted 1 in 10 in $10 \%$ (v/v) glycerol broth and immediately frozen in solid carbon dioxide or in liquid nitrogen for transport to London (Crowther, 1971). The samples were stored at $-50^{\circ} \mathrm{C}$.

\section{Isolation of clostridia}

Ten-fold dilutions of the specimens were prepared in quarter-strength Ringer's solution containing peptone $0.5 \%(\mathrm{w} / \mathrm{v}) ; 0 \cdot 1-\mathrm{ml}$ samples of appropriate dilutions were spread on the surface of plates of egg-yolk lactose agar containing $100 \mu \mathrm{g}$ neomycin per ml (modified

Received 28 April 1975; accepted 4 July 1975.

J. MED. MICROBIOL,-VOL. 9 (1976) 
medium of Willis and Hobbs, 1958). The remainder of each dilution was heated at $70^{\circ} \mathrm{C}$ for $10 \mathrm{~min}$. and $0.1-\mathrm{ml}$ samples of appropriate dilutions were spread on the surface of eggyolk lactose agar.

Seeded plates were packed into anaerobic jars which were then evacuated and filled with hydrogen. After a few minutes, the jars were re-evacuated and filled with a gas mixture containing $30 \% \mathrm{CO}_{2}$ and $70 \%$ hydrogen. They were incubated at $37^{\circ} \mathrm{C}$ for 2 days. Cold " D " catalyst was used in the anaerobic jars (Englehard Industries, Cinderford, Gloucestershire).

From each of the plates spread with unheated material, two colonies with an opalescent halo were picked, and from the isolation plates spread with heated material 10 colonies without an opalescent halo were picked. The colonies were streaked on egg-yolk lactose agar plates without neomycin for purification. Sporing aerobic bacilli and faecal streptococci that survived heat treatment were discarded. Pure strains were stored at $4^{\circ} \mathrm{C}$ in Robertson's meat medium.

\section{Biochemical tests}

Liquid media for biochemical tests were distributed in 5-ml screw-capped bottles and seeded with two drops of actively growing culture from Robertson's cooked meat medium. The tops of the bottles were loosened before incubation in an anaerobic jar containing an atmosphere of $30 \% \mathrm{CO}_{2}$ and $70 \% \mathrm{H}_{2}$.

Fermentation tests. The fermentation tests were modifications of those described by Cato et al. (1970); $0.5 \mathrm{~g}$ of aesculin or $1.0 \mathrm{~g}$ of other test carbohydrate was added to a $100-\mathrm{ml}$ volume of basal medium containing peptone $2.0 \mathrm{~g}$, yeast extract $1.0 \mathrm{~g}$, cysteine hydrochloride $0.05 \mathrm{~g}$, sodium formaldehyde sulphoxylate $0.03 \mathrm{~g}, \mathrm{CaCl}_{2} 0.001 \mathrm{~g}, \mathrm{MgSO}_{4} 0.001 \mathrm{~g}, \mathrm{KH}_{2} \mathrm{PO}_{4}$ $0.005 \mathrm{~g}, \mathrm{NaHCO}_{3} 0.05 \mathrm{~g}$, and $\mathrm{NaCl} 0.01 \mathrm{~g}$. The $p \mathrm{H}$ was adjusted to $7 \cdot 1 \pm 0 \cdot 1$ and the media were dispensed in volumes of $4.5 \mathrm{ml}$ before autoclaving at $115^{\circ} \mathrm{C}$ for $20 \mathrm{~min}$. Cultures were incubated anaerobically at $37^{\circ} \mathrm{C}$ for 3 days. The final $p \mathrm{H}$ of media was estimated by the addition of two drops of bromocresol purple indicator (BDH). Fermentation of aesculin, fructose, glucose, lactose, maltose, mannose, salicin, starch, sucrose and xylose was tested. The reaction of the strains in litmus milk was also examined.

Microfermentation tests were used for the study of the clostridia isolated from specimens collected in Wales. Sterile $2 \%(\mathrm{w} / \mathrm{v})$ solutions of glucose, lactose, maltose, mannitol, salicin, sucrose and urea were dispensed aseptically in 100- $\mu$ l amounts into sterile multi-well plastic trays with a Canalco Autotiter IV multi-channel dispensing and diluting apparatus (Fisons Scientific Apparatus, Leicester). Cultures of bacteria were added to sugar solutions from a 100- $\mu 1$ automatic pipette (Finnpipette, Jencons Ltd). The basal medium contained gelatin $0.3 \mathrm{~g}$, agar $0.1 \mathrm{~g}$, tryptone $1.0 \mathrm{~g}$, yeast extract $0.3 \mathrm{~g}$, cysteine hydrochloride $0.05 \mathrm{~g}$, sodium formaldehyde sulphoxylate $0.03 \mathrm{~g}, \mathrm{CaCl}_{2} 0.001 \mathrm{~g}, \mathrm{MgSO}_{4} 0.001 \mathrm{~g}$, biotin solution $(1.25 \mathrm{mg}$ per $100 \mathrm{ml}$ ) $0.4 \mathrm{ml}$, haemin-menadione solution (haemin $50 \mathrm{mg}$ and menadione $5 \mathrm{mg}$ per $100 \mathrm{ml}) 1.0 \mathrm{ml}$, rumen fluid $20 \mathrm{ml}$ and distilled water $80 \mathrm{ml}$. The trays of inoculated sugars were incubated for 3 days at $37^{\circ} \mathrm{C}$ in an anaerobic jar containing an atmosphere of $30 \% \mathrm{CO}_{2}$ and $70 \% \mathrm{H}_{2}$. The final $p \mathrm{H}$ was estimated with bromocresol purple indicator. Preliminary results showed that these micro-fermentation tests gave results comparable to those of conventional fermentation tests. Similar micro-tests have been used for the identification of enterobacteria and streptococci (Huhtanen, Naghski and Dellamonica, 1972; JayneWilliams, 1975).

Test for starch hydrolysis. Two or three drops of Lugol's iodine were added to a 3-day culture in the starch medium. A negative test was denoted by the development of a blue colour.

Test for aesculin hydrolysis. Two or three drops of a $1 \%(\mathrm{w} / \mathrm{v})$ solution of ferric chloride were added to a 3-day culture in aesculin medium. A positive test was denoted by the development of a black colour.

Test for gelatin liquefaction. The test cultures were seeded into Robertson's cooked meat medium with added charcoal gelatin disks (Oxoid). The appearance of free charcoal particles in the medium after incubation for 14 days at $37^{\circ} \mathrm{C}$ indicated liquefaction of the gelatin. 
Test for nitrate reduction and indole production. Nitrate, nitrite and indole were detected by conventional procedures (Cowan and Steel, 1965) in cultures grown anaerobically for $72 \mathrm{~h}$ in indole-nitrate medium (Baltimore Biological Laboratories, USA).

Nagler's reaction. On one-half of an egg-yolk-agar plate two or three drops of $C$. welchii (C. perfringens) antitoxin (Burroughs Wellcome Ltd) were spread and allowed to dry. The plate was then streak-inoculated with cultures of clostridia. Plates were examined after anaerobic incubation for 3 days. Inhibition by antiserum of the production of an opalescent halo was a positive reaction.

Test for toxin production. Cultures were seeded into Robertson's cooked-meat broth previously enriched with $1 \mathrm{ml}$ of a sterile glucose solution $(10 \% \mathrm{w} / \mathrm{v})$ and $0.5 \mathrm{ml}$ of a sterile solution of calcium chloride $(25 \% \mathrm{w} / \mathrm{v})$ and incubated overnight. CBA-strain mice were challenged intraperitoneally with $0.5 \mathrm{ml}$ of the supernate. The identity of the toxin was determined by neutralisation tests involving the incubation of $1.3-\mathrm{ml}$ volumes of the culture supernate with 0.2-ml volumes of specific antisera (Burroughs Wellcome Ltd) before injection into the mice. Only strains that could be ascribed to toxigenic species on biochemical grounds were tested.

\section{Gas-liquid chromatography}

Preparation of the sample. A 4-ml volume of a 3-day culture in $1 \%$ glucose broth (Cato et al., 1970) was acidified with $0.5 \mathrm{ml}$ of $9 \mathrm{M} \mathrm{H}_{2} \mathrm{SO}_{4}$ and extracted with $4 \mathrm{ml}$ diethyl ether. After centrifugation to break the emulsion, the ether layer was pipetted off and dried over magnesium sulphate. Reference solutions were prepared as described by Cato et al. (1970). Controls were of uninoculated glucose broth. Pyruvic, lactic and succinic acids are unstable at the operating temperature of the gas chromatograph. These acids were detected by prior preparation of their methyl esters, which are stable and readily separate on the column. Freshly prepared diazomethane (de Boer and Backer, 1954) was used as the methylating agent, two to three drops being added to a portion of the extract.

Chromatographic conditions. Analyses were performed on a Pye 104 chromatograph fitted with a flame-ionisation detector and a $150-\mathrm{cm}$ glass column packed with Diatomite $C$ that had been treated with phosphoric acid and impregnated with $10 \%$ polyethylene glycol (prepared column no. 12440/2/10 PMP/01F78 available from Pye-Unicam Ltd, Cambridge). The operating temperature was $125^{\circ} \mathrm{C}$ and the carrier gas was oxygen-free $\mathrm{N}_{2}$ passing through at $30 \mathrm{ml}$ per min. A 1- 1 l portion of the sample for analysis was injected on to the column.

Head-space analysis. For some strains, analyses of cultures for the presence of volatile acids were performed on a Perkin Elmer F.40 automatic head-space analyser.

A 4-ml volume of a glucose-broth culture was pipetted into the vial provided and $0.1 \mathrm{ml}$ of $9 \mathrm{M} \mathrm{H}_{2} \mathrm{SO}_{4}$ was added. The vial was closed with a $20-\mathrm{mm}$ butyl rubber serum stopper and the stopper sealed in position with an aluminium ring. The sealed vials were placed in the water bath at $90^{\circ} \mathrm{C}$ and left for $30 \mathrm{~min}$. to equilibrate. The machine automatically sampled and analysed the vapour phase of each vial.

The chromatograph was fitted with a flame-ionisation detector and a 2-metre stainless steel column packed with $15 \%$ Carbowax $20 \mathrm{M}$ and $2 \%$ phosphoric acid Chromosorb W 80 100 mesh (prepared column no. B.S.13865, part no. 498-1222 available from Perkin Elmer Ltd, Beaconsfield). The carrier gas was oxygen-free $\mathrm{N}_{2}$ passing at $30 \mathrm{ml}$ per min. The column-oven temperature was $130^{\circ} \mathrm{C}$ and the detector oven was at $200^{\circ} \mathrm{C}$. A 5 -second injection period was used.

\section{Identification of the isolates}

Biochemical tests were performed and volatile acid end-products analysed on all the isolates. When necessary, tests for the production of toxins and non-volatile acid endproducts were also performed. Isolates were assigned to species as defined by Buchanan and Gibbons (1974), with reference also to Smith and Holdeman (1968), Willis (1969) and Holdeman and Moore (1972).

In view of our interest in the metabolic significance of clostridia in the intestine, the isolates were assigned to three main groups on the basis of analysis of the end-products of glucose

J. MED. MCROBIOL.-VOL. 9 (1976) 
TABLE I

The number of clostridia in faeces from various sources

\begin{tabular}{|c|c|c|c|}
\hline \multirow{2}{*}{$\begin{array}{c}\text { Country of } \\
\text { origin }\end{array}$} & \multirow{2}{*}{$\begin{array}{l}\text { Number of } \\
\text { subjects }\end{array}$} & \multicolumn{2}{|c|}{$\begin{array}{c}\log _{10} \text { number of viable clostridia per gram } \\
\text { of faeces: } \\
\text { mean (and range*) }\end{array}$} \\
\hline & & $\begin{array}{c}\text { Clostridia producing } \\
\text { lecithinase }\end{array}$ & $\begin{array}{c}\text { Clostridia not } \\
\text { producing lecithinase } \dagger\end{array}$ \\
\hline $\begin{array}{l}\text { England } \\
\text { Scotland } \\
\text { Wales } \\
\text { USA } \\
\text { Uganda } \\
\text { Japan } \\
\text { Hong Kong }\end{array}$ & $\begin{array}{r}36 \\
11 \\
65 \\
8 \\
19 \\
11 \\
25\end{array}$ & $\begin{array}{l}4 \cdot 2(\mathrm{D}-7 \cdot 4) \\
4 \cdot 1(\mathrm{D}-7 \cdot 0) \\
4 \cdot 2(\mathrm{D}-7 \cdot 7) \\
3 \cdot 7(\mathrm{D}-6 \cdot 2) \\
4 \cdot 0(\mathrm{D}-7 \cdot 0) \\
4 \cdot 7(2 \cdot 4-7 \cdot 6) \\
4 \cdot 7(\mathrm{D}-7 \cdot 1)\end{array}$ & $\begin{array}{l}5 \cdot 7(\mathrm{D}-6 \cdot 7) \\
5 \cdot 6(3 \cdot 2-6 \cdot 9) \\
4 \cdot 7(\mathrm{D}-7 \cdot 2) \\
5 \cdot 4(\mathrm{D}-6 \cdot 5) \\
5 \cdot 2(\mathrm{D}-7 \cdot 2) \\
5 \cdot 5(3 \cdot 8-6 \cdot 7) \\
5 \cdot 5(3 \cdot 2-7 \cdot 2)\end{array}$ \\
\hline
\end{tabular}

* $\mathrm{D}=$ less than 100 organisms per gram of faeces.

+ Counted after heating the specimen at $70^{\circ} \mathrm{C}$ for $10 \mathrm{~min}$.

TABLE II

The source and percentage of specimens yielding one, two, three, or more species of clostridia

\begin{tabular}{l|cccc}
\hline $\begin{array}{l}\text { Country of } \\
\text { origin }\end{array}$ & \multicolumn{4}{c}{$\begin{array}{c}\text { Percentage number of specimens yielding the } \\
\text { stated number of species per sample }\end{array}$} \\
\cline { 2 - 5 } & 1 & 2 & 3 & 4 or more \\
\hline England & 19 & 33 & 19 & 28 \\
Sccotland & 36 & 27 & 9 & 27 \\
Wales & 26 & 29 & 23 & 21 \\
USA & $37 \cdot 5$ & $37 \cdot 5$ & 25 & $\ldots$ \\
Uganda & 32 & 47 & 21 & $\ldots$ \\
Japan & $45 \cdot 5$ & 27 & 18 & 9 \\
Hong Kong & 16 & 32 & 28 & 24 \\
\hline
\end{tabular}

$\ldots=$ none detected.

metabolism. The first group comprised clostridia that produced acetic acid as their major metabolic product, the second organisms that produce butyric acid alone or with acetic acid as their major products, and the third group clostridia that produce a complex mixture of acids. Most of the frankly proteolytic clostridia are found in this third group.

\section{RESULTS}

The number of clostridia detected was similar in all the groups of specimens studied (table I); clostridia were detected in all save one of the specimens. Only one species of clostridium was isolated from $26 \%$ of the samples, and $20 \%$ yielded four species or more (table II).

Most of the clostridia isolated from specimens from England, Scotland, Wales and the USA, were assigned to species; only $4 \%$ of these strains were 
TABLE III

The identity of the major groups of isolates

\begin{tabular}{|c|c|c|c|c|c|c|c|}
\hline \multirow{2}{*}{$\begin{array}{l}\text { Identity of } \\
\text { isolate }\end{array}$} & \multicolumn{7}{|c|}{ Number of strains isolated from } \\
\hline & England & Scotland & Wales & USA & Uganda & Japan & Hong Kong \\
\hline $\begin{array}{l}\text { Group I } \\
\text { Clostridium indolis } \\
\text { C. putrefaciens } \\
\text { C. ramosum } \\
\text { Others } \\
\text { Unidentified }\end{array}$ & $\begin{array}{r}3 \\
3 \\
10 \\
6 \\
23\end{array}$ & $\begin{array}{l}4 \\
\cdots \\
\cdots \\
1 \\
\cdots\end{array}$ & $\begin{array}{r}\dddot{34} \\
29 \\
1 \\
4\end{array}$ & $\begin{array}{r}\dddot{1} \\
4 \\
2 \\
\cdots\end{array}$ & $\begin{array}{r}4 \\
\cdots \\
\dddot{2} \\
2 \\
4\end{array}$ & $\begin{array}{r}2 \\
\dddot{8} \\
1 \\
1\end{array}$ & $\begin{array}{l}\cdots \\
\cdots \\
4 \\
4 \\
7\end{array}$ \\
\hline $\begin{array}{l}\text { Group II } \\
\text { C. felsineum } \\
\text { C. paraputrificum } \\
\text { C. perfringens } \\
\text { C. rectum } \\
\text { C. sporosphaeroides } \\
\text { Others } \\
\text { Unidentified }\end{array}$ & $\begin{array}{r}8 \\
49 \\
31 \\
4 \\
5 \\
29 \\
\ldots\end{array}$ & $\begin{array}{r}8 \\
33 \\
9 \\
\ldots \\
\dddot{16} \\
\ldots\end{array}$ & $\begin{array}{r}103 \\
67 \\
11 \\
31 \\
20 \\
4\end{array}$ & $\begin{array}{c}\cdots \\
9 \\
10 \\
\cdots \\
\cdots \\
\cdots\end{array}$ & $\begin{array}{r}7 \\
6 \\
21 \\
2 \\
\dddot{7} \\
15\end{array}$ & $\begin{array}{l}\cdots \\
71 \\
11 \\
\cdots \\
8 \\
\cdots\end{array}$ & $\begin{array}{c}1 \\
8^{*} \\
3 \dagger \\
6 \\
\dddot{15} \\
19\end{array}$ \\
\hline $\begin{array}{l}\text { Group III } \\
\text { C. bifermentans } \\
\text { C. cadaveris } \\
\text { C. sporogenes } \\
\text { Others } \\
\text { Unidentified }\end{array}$ & $\begin{array}{c}9 \\
1 \\
7 \\
3 \\
\cdots\end{array}$ & $\begin{array}{r}20 \\
7 \\
8 \\
\cdots \\
\cdots\end{array}$ & $\begin{array}{r}12 \\
\cdots \\
3 \\
1 \\
\cdots\end{array}$ & $\begin{array}{r}3 \\
\dddot{1} \\
1 \\
\cdots\end{array}$ & $\begin{array}{c}5 \\
3 \\
\cdots \\
2 \\
\cdots\end{array}$ & $\begin{array}{c}3 \\
\dddot{1} \\
\cdots \\
\dddot{4}\end{array}$ & $\begin{array}{l}2 \dagger \\
\ldots+ \\
\ldots \dagger \\
\cdots\end{array}$ \\
\hline
\end{tabular}

$\ldots=$ none detected.

* Only one of these strains was able to dehydrogenate the steroid nucleus.

$\dagger$ Lecithinase-producing colonies were subcultured from three specimens.

unidentified. In contrast, $29 \%$ of the strains from Uganda, Japan and Hong Kong remain unidentified.

C. perfringens, C. bifermentans and C. paraputrificum were isolated from all the groups of specimen examined (table III); $C$. perfringens was equally common in all groups, whereas $C$. bifermentans was most common in specimens from Scotland. C. paraputrificum was common in specimens from England, Scotland, Wales and the USA but occurred less frequently in specimens from Uganda, Japan and Hong Kong (table IV). Of the eight strains of $C$. paraputrificum obtained from specimens originating in Hong Kong, seven were atypical in that they were unable to dehydrogenate the steroid nucleus and did not hydrolyse aesculin.

Many other species of clostridia were detected during this study; however, most were isolated so infrequently that no comment can be made as to their distribution (table V).

\section{Discussion}

The organisms isolated in this study represent the most numerous clostridia present in the specimens examined that (1) were lecithinase positive or (2) produced spores. Attebury, Sutter and Finegold (1974) and Moore and 
TABLE IV

The percentage number of specimens yiclding the major groups of isolates

\begin{tabular}{|c|c|c|c|c|c|c|c|}
\hline \multirow{2}{*}{$\begin{array}{l}\text { Identity of } \\
\text { isolate }\end{array}$} & \multicolumn{7}{|c|}{ Percentage number of specimens from } \\
\hline & England & Scotland & Wales & USA & Uganda & Japan & Hong Kong \\
\hline $\begin{array}{l}\text { Group I } \\
\text { C. indolis } \\
\text { C. putrefaciens } \\
\text { C. ramosum } \\
\text { Others } \\
\text { Unidentified }\end{array}$ & $\begin{array}{r}6 \\
6 \\
17 \\
14 \\
33\end{array}$ & $\begin{array}{l}36 \\
\cdots \\
\cdots \\
9 \\
\cdots\end{array}$ & $\begin{array}{l}21 \cdot 5 \\
12 \\
1 \cdot 5 \\
5\end{array}$ & $\begin{array}{l}12 \cdot 5 \\
37 \cdot 5 \\
25 \\
\cdots\end{array}$ & $\begin{array}{l}16 \\
\cdots \\
\dddot{10} \cdot 5 \\
16\end{array}$ & $\begin{array}{r}9 \\
27 \\
9 \\
9\end{array}$ & $\begin{array}{l}\ldots \\
13 \\
16 \\
12 \\
28\end{array}$ \\
\hline $\begin{array}{l}\text { Group II } \\
\text { C. felsineum } \\
\text { C. paraputrificum } \\
\text { C. perfringens } \\
\text { C. rectum } \\
\text { C. sporosphaeroides } \\
\text { Others } \\
\text { Unidentified }\end{array}$ & $\begin{array}{l}11 \\
61 \\
53 \\
11 \\
11 \\
39 \\
\ldots\end{array}$ & $\begin{array}{l}45 \cdot 5 \\
91 \\
54 \cdot 5 \\
\ldots \\
\ldots \\
64 \\
\cdots\end{array}$ & $\begin{array}{l}43 \\
60 \\
14 \\
21 \cdot 5 \\
21 \cdot 5 \\
5\end{array}$ & $\begin{array}{l}75 \\
75 \\
\ldots \\
\dddot{25} \\
\ldots\end{array}$ & $\begin{array}{l}10 \cdot 5 \\
26 \\
53 \\
10 \cdot 5 \\
\dddot{16} \\
47\end{array}$ & $\begin{array}{l}36 \\
64 \\
\ldots \\
\ldots \\
27\end{array}$ & $\begin{array}{l}4 \\
12^{*} \\
12 \dagger \\
20 \\
\dddot{56} \\
44\end{array}$ \\
\hline $\begin{array}{l}\text { Group III } \\
\text { C. bifermentans } \\
\text { C. cadaveris } \\
\text { C. sporogenes } \\
\text { Others } \\
\text { Unidentified }\end{array}$ & $\begin{array}{r}19 \\
3 \\
17 \\
8 \\
\ldots\end{array}$ & $\begin{array}{l}73 \\
54 \cdot 5 \\
45 \cdot 5 \\
\ldots \\
\ldots\end{array}$ & $\begin{array}{l}17 \\
\cdots \\
3 \\
1 \cdot 5 \\
\cdots\end{array}$ & $\begin{array}{l}25 \\
\dddot{12} \cdot 5 \\
12 \cdot 5 \\
\ldots\end{array}$ & $\begin{array}{l}21 \\
10 \cdot 5 \\
\ldots \\
10 \cdot 5 \\
\ldots\end{array}$ & $\begin{array}{r}18 \\
\dddot{9} \\
\dddot{27}\end{array}$ & $\begin{array}{l}8 \dagger \\
\ldots \\
\ldots \dagger \\
\ldots \\
16\end{array}$ \\
\hline
\end{tabular}

$\cdots=$ none detected.

* Only one of these strains was able to dehydrogenate the steroid nucleus.

$\uparrow$ Lecithinase-producing colonies were subcultured from only three specimens.

Holdeman (1974) isolated C. aminovalericum, C. oroticum, C. ramosum, $C$. innocuum, $C$. paraputrificum, $C$. perfringens, and $C$. sporosphaeroides from faeces by use of selective media and by subculture of large numbers of colonies from non-selective media. Clostridia designated as groups " $A$ " and " $D$ " were detected and described by Moore and Holdeman (1974) during their study of Japanese-Hawaiians. The organisms detected in the latter studies may well have been present as vegetative organisms, and indeed the high bacterial counts reported by these investigators, compared with counts in this study, support this contention. The use of heat-treated specimens enabled us to detect a wider range of bacterial species than did these other workers, but at the expense of a reduction in bacterial numbers.

The use of serial dilutions inevitably leads to the masking of organisms present in small numbers by those in larger numbers and it is likely that clostridial flora of faeces is even more diverse than appears in the present study. Further, the isolation rate of any particular species is affected. Thus, the lower-than-expected rates for the isolation of $C$. perfringens may in part be accounted for by the masking of these organisms in mixed populations. If suitable enrichment procedures were employed it is likely that a much higher 
TABLE V

The identity of the minor groups of isolates

\begin{tabular}{|c|c|c|}
\hline Species & $\begin{array}{l}\text { Number of subjects } \\
\text { yielding the stated } \\
\text { species }\end{array}$ & Countries of origin \\
\hline $\begin{array}{l}\text { Group I } \\
\text { C. aminovalericum } \\
\text { C. limosum } \\
\text { C. oroticum } \\
\text { C. } \text { sphenoides }\end{array}$ & $\begin{array}{l}2 \\
3 \\
4 \\
7\end{array}$ & $\begin{array}{l}\text { England } \\
\text { USA, Japan, Hong Kong } \\
\text { England, USA, Uganda } \\
\text { England, Scotland, Wales, Hong Kong }\end{array}$ \\
\hline $\begin{array}{l}\text { Group II } \\
\text { C. acetobutylicum } \\
\text { C. aurantibutyricum } \\
\text { C. bejerinkii } \\
\text { C. butyricum } \\
\text { C. chauvoei } \\
\text { C. innocuum } \\
\text { C. malenominatum } \\
\text { C. pasteurianum } \\
\text { C. plagrum } \\
\text { C. pseudotetanicum } \\
\text { C. sartagoformum }\end{array}$ & $\begin{array}{l}1 \\
1 \\
2 \\
2 \\
7 \\
8 \\
3 \\
3 \\
1 \\
3 \\
9\end{array}$ & $\begin{array}{l}\text { England, Wales } \\
\text { Hong Kong } \\
\text { Hong Kong } \\
\text { Wales, USA } \\
\text { England, Scotland, Uganda and Japan } \\
\text { England, Hong Kong } \\
\text { USA, Japan } \\
\text { Scotland, Uganda } \\
\text { Scotland } \\
\text { England } \\
\text { England, Wales }\end{array}$ \\
\hline $\begin{array}{l}\text { Group } \mathrm{A}^{*} \\
\text { Group } \mathrm{D}^{*}\end{array}$ & $\begin{array}{l}6 \\
3\end{array}$ & $\begin{array}{l}\text { England, Wales, Hong Kong } \\
\text { England, Hong Kong }\end{array}$ \\
\hline $\begin{array}{l}\text { Group III } \\
\text { C. difficile } \\
\text { C. glycolicum } \\
\text { C. irregularis } \\
\text { C. putrificum } \\
\text { C. sticklandii }\end{array}$ & $\begin{array}{l}1 \\
1 \\
1 \\
3 \\
1\end{array}$ & $\begin{array}{l}\text { USA } \\
\text { England } \\
\text { Uganda } \\
\text { England, Hong Kong } \\
\text { Uganda }\end{array}$ \\
\hline
\end{tabular}

* Un-named groups described by Moore and Holdeman (1974). These organisms may constitute new species.

rate of isolation would be achieved both for $C$. perfringens and other prominent clostridia.

Clostridia that produce lecithinase are of particular interest because of the importance of $C$. perfringens. The analysis of the acid end-products of glucose metabolism is an additional aid to their identification. C. limosum, C. perfringens and $C$. bifermentans all produce lecithinase detectable on media containing egg-yolk, but these species differ widely with respect to their endproducts. $C$. sordellii differs from the other organisms in this group in its ability to hydrolyse urea and can also be distinguished from $C$. perfringens and C. bifermentans on the basis of end-product analysis (Holdeman and Moore, 1972). C. barati, an organism resembling C. perfringens, was isolated from faeces by Attebery et al. (1974), but was not detected in this study.

C. paraputrificum was isolated more often from samples from England, Scotland, Wales and the USA than from samples from other areas. The relationship of these isolation rates to incidence of cancer of the colon is 


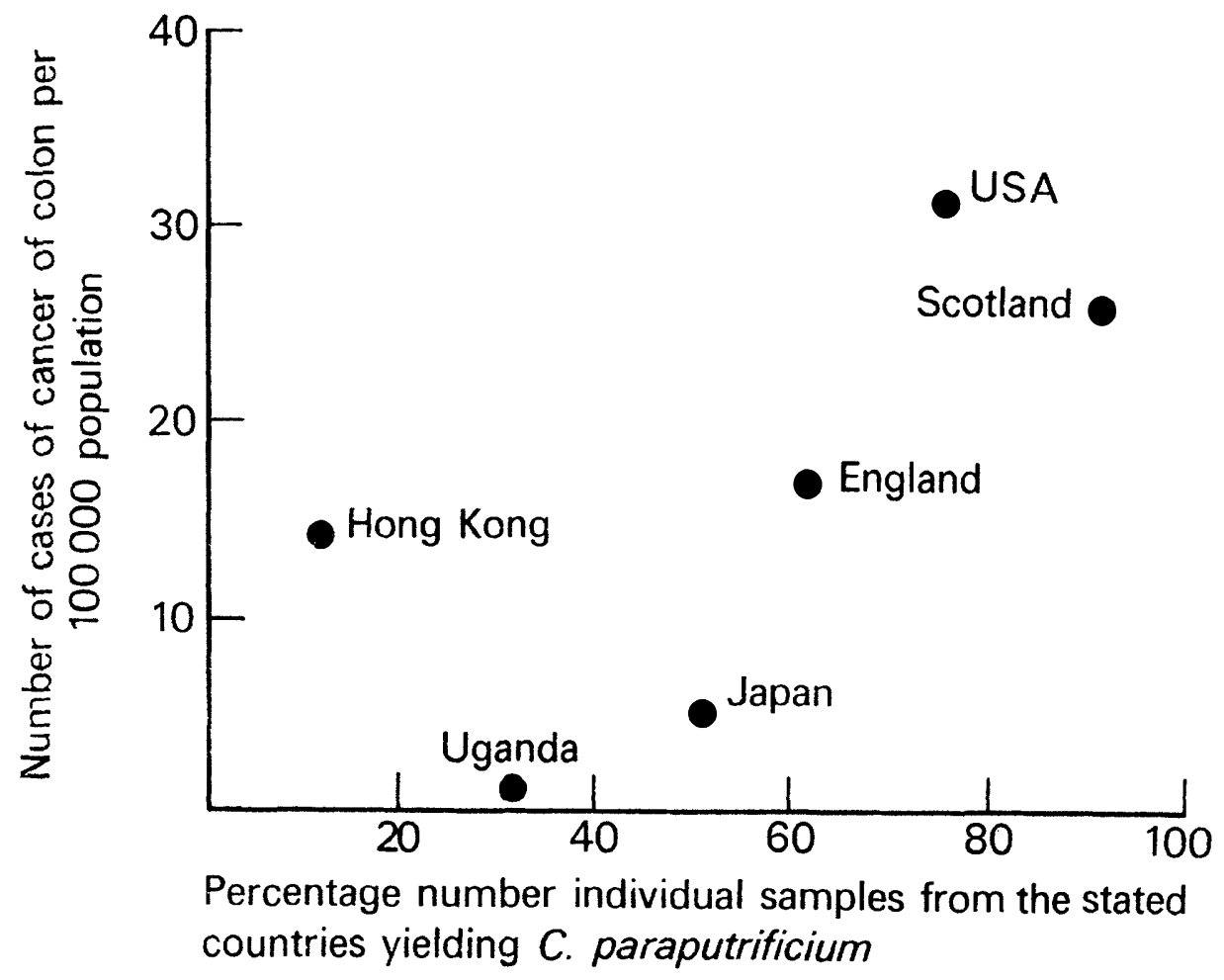

FIGURE.- The relation of the rates of isolation of $C$. paraputrificum to the incidence of cancer of the colon (incidence data of Doll, 1969).

represented in the figure. This relationship is consistent with our hypothesis that $C$. paraputrificum, because of its ability to dehydrogenate the steroid nucleus, is implicated in the causation of cancer of the colon. The results from Hong Kong need explanation; the incidence data quoted relate to the whole population, whereas incidence data for the sub-population examined by us are not yet available. In a retrospective study of patients with cancer of the large bowel, $C$. paraputrificum was isolated more often from the faeces of cancer patients than of other patients (Hill et al., 1975). The results of the present study, when considered in conjunction with those of our studies on cancer patients, provide a prima facie case for the involvement of $C$. paraputrificum in the aetiology of cancer of the colon and underline the need for more information about the factors allowing the persistence of particular clostridia in the gut.

\section{SUMMARY}

Clostridia were isolated from human faecal samples from England, Scotland, Wales, USA, Hong Kong, Uganda and Japan. Strains were identified on the 
basis of various biochemical reactions and on the type of fatty acid produced from glucose. Analysis of these acids was by gas-liquid chromatography.

Clostridium paraputrificum was common in stool samples from England, Scotland, Wales and USA, but rare in samples from Hong Kong, Uganda and Japan.

\section{REFERENCES}

Aries, V., Crowther, J. S., Drasar, B. S., Hill, M. J. and Williams, R. E. O. 1969. Bacteria and the aetiology of cancer of the large bowel. Gut, 10, 334.

Aries, V. C., Goddard, P. AND Hill, M. J. 1971. Degradation of steroids by intestinal bacteria. III. 3-Oxo-5 $\beta$-steroid $\triangle^{1}$ dehydrogenase and 3-oxo-5 $\beta$-steroid $\triangle^{4}$-dehydrogenase. Biochim. biophys. Acta, 248, 482.

ATtEBERY, H. R., SUTTER, V. L. AND Finegold, S. M. 1974. Normal human intestinal flora: role in disease. In Anaerobic bacteria, edited by A. Balows, R. M. De Haan, V. R. Dowell, and L. B. Guze, Springfield, Ill., p. 81.

BoER, T. J. DE AND BACKER, H. J. 1954. A new method for the preparation of diazomethane. Eecl. Trav. Chim. Pays-Bas Belg., 73, 229.

Buchanan, R. E. AND Gibbons, N. E. 1974. Bergey's Manual of determinative bacteriology, 8th ed., Baltimore, p. 551.

Capek, A., Hanc, O. AND TAdra, M. 1966. Microbial transformations of steroids, Prague.

Cato, E. P., Cummins, C. S., Holdeman, L. V., Johnson, J. L., Moore, W. E. C., Smibert, R. M. AND SMrTH, L. DS. 1970. Outline of clinical methods in anaerobic bacteriology, Blacksburg, Va.

CowAn, S. T. AND SteEl, K. J. 1965. Manual for the identification of medical bacteria, London.

CrowTHER, J. S. 1971. Transport and storage of faeces for bacteriological examination. J. appl. Bact., 34, 477.

Doll, R. 1969. The geographical distribution of cancer. Br. J. Cancer, 23, 1.

Goddard, P., Fernandez, F., West, B., Hill, M. J. and Barnes, P. 1975. The nuclear dehydrogenation of steroids by intestinal bacteria. J. med. Microbiol., 8, 429.

hill, M. J., Crowther, J. S., Drasar, B. S., Hawksworth, G., Aries, V. and Williams, R. E. O. 1971. Bacteria and aetiology of cancer of large bowel. Lancet, 1, 95.

Hill, M. J., Drasar, B. S., Williams, R. E. O., Meade, T. W., Cox, A. G., Simpson, J. E. P. AND MORSON, B. C. 1975. Faecal bile-acids and clostridia in patients with cancer of the large bowel. Lancet, 1,535 .

Holdeman, L. V. AND MOORE, W. E. C. 1972. Anaerobe laboratory manual, Blacksburg, $\mathrm{Va}$.

Huhtanen, C. N., Naghski, J. and Dellamonica, E. S. 1972. Microfermentation series for identification of single colonies of Enterobacteriaceae. Appl. Microbiol., 24, 618.

JAYNE-WILLIAMS, D. J. 1975. Miniaturised methods for characterisation of bacterial isolates. J. appl. Bact., 38, 305.

Moore, W. E. C. ANd Holdeman, L. V. 1974. Human fecal flora: the normal flora of 20 Japanese-Hawaiians. Appl. Microbiol., 27, 961.

Norman, A. AND GruBb, R. 1955. Hydrolysis of conjugated bile acids by clostridia and enterococci. Acta. path. microbiol. scand., 36, 537.

Peach, S., Fernandez, F., Johnson, K. and Drasar, B. S. 1974. The non-sporing anaerobic bacteria in human faeces. J. med. Microbiol., 7, 213.

Smith, L. DS. AND Holdeman, L. V. 1968. The pathogenic anaerobic bacteria, Springfield, Ill.

WILLIS, A. T. 1969. Clostridia of wound infection. London.

WILlis, A. T. AND HoBBS, G. 1958. A medium for the identification of clostridia producing opalescence in egg-yolk emulsions. J. Path. Bact., 75, 299. 